\title{
Jun Aoki Interview
}

\section{Andrew Barrie}

Jun Aoki is principal of Jun Aoki \& Associates. After graduating with a Masters degree from Tokyo University in 1982, Aoki worked at Arata Isozaki \& Associates before establishing his own Tokyo-based practice in 1991. His celebrated early projects include the Yusuikan swimming pool complex (1993) and the Fukushima Lagoon Museum (1997), which won the Architectural Institute of Japan Annual Award. Aoki is best known for innovative boutiques for Louis Vuitton and the recently completed Aomori Museum of Art (2007), a commission he won through a major international competition. Aoki's work has been the subject of an exhibition at Galley MA in Tokyo, and a number of monographs including Complete Works Volume I (2004) and Volume 2 (2007). Several volumes of his writings have been published.

Andrew Barrie interviewed Jun Aoki at the School of Architecture \& Planning, The University of Auckland, on 3I March 2008.
AB [to the audience]: As a student, it always struck me that it wasn't necessarily very helpful to learn how to design a museum or a concert hall. What I needed to know was what to do next - how to use my time at university, how to get a job, how to establish myself as a young architect. It's often quite difficult to learn about the early days of the architects we're interested in. So, given that this is a seminar for students, we thought we'd talk to Aoki-san about his youth, and ask what advice he has for those starting out on their architecture careers.

AB [to Aoki]: When did you decide to become an architect? What influenced this decision? Any particular architects or buildings?

JA: When I was a high school student, I knew I couldn't work for an ordinary company, because I wanted to be creative and because I can't wake up at the same time every day. So, my first choice was to be a film director, and my other ideas were to be a novelist or a writer, or perhaps an architect. For me, directing films is very, very interesting because when I was a child I really liked to watch TV [laughs]. However, I didn't know how to become a director, so I had two options - novelist or architect. I thought that if I studied architecture then I'd have a route towards becoming an architect. So, for me, becoming an architect was easier, so that's the decision I made.

Anyway, in my family being an architect isn't so special, because my aunt and one of my father's best friends are architects. During my high school years I visited architects' studios several times, so I knew a little bit about what they do. For me it was very, very interesting, and it didn't look like work but like play.

What kind of education did you have at middle school and high school?

It was very typical for Japan. We start going to school from the age of six, and it's compulsory until children are twelve or thirteen years old. I was a very ordinary student. At that time, I very much liked art and I liked to paint.

Do you still have time to paint?

Actually, no! [laughs] Nowadays, I don't want to paint but to make models, even just very conceptual models. After I decided to become an architect, my approach to art changed. When I was a child, art was painting pictures, but now it's threedimensional things. I prefer sculpture or installation art to paintings.

You went to Tokyo University. Perhaps Kiwis won't understand the significance of that. Tokyo University is Japan's number one university, and is extremely tough to get into. Schoolchildren spend years going to cram school and staying up late studying to get in. Did you go through this kind of process?

When I was in my last years of high school, my aunt told me I couldn't enter Tokyo University like my father - he had studied at Tokyo University. So, I suddenly decided to try for Tokyo University. At that time I didn't want to be an architect, so I applied to the literature department. My test for Japanese went ex- 

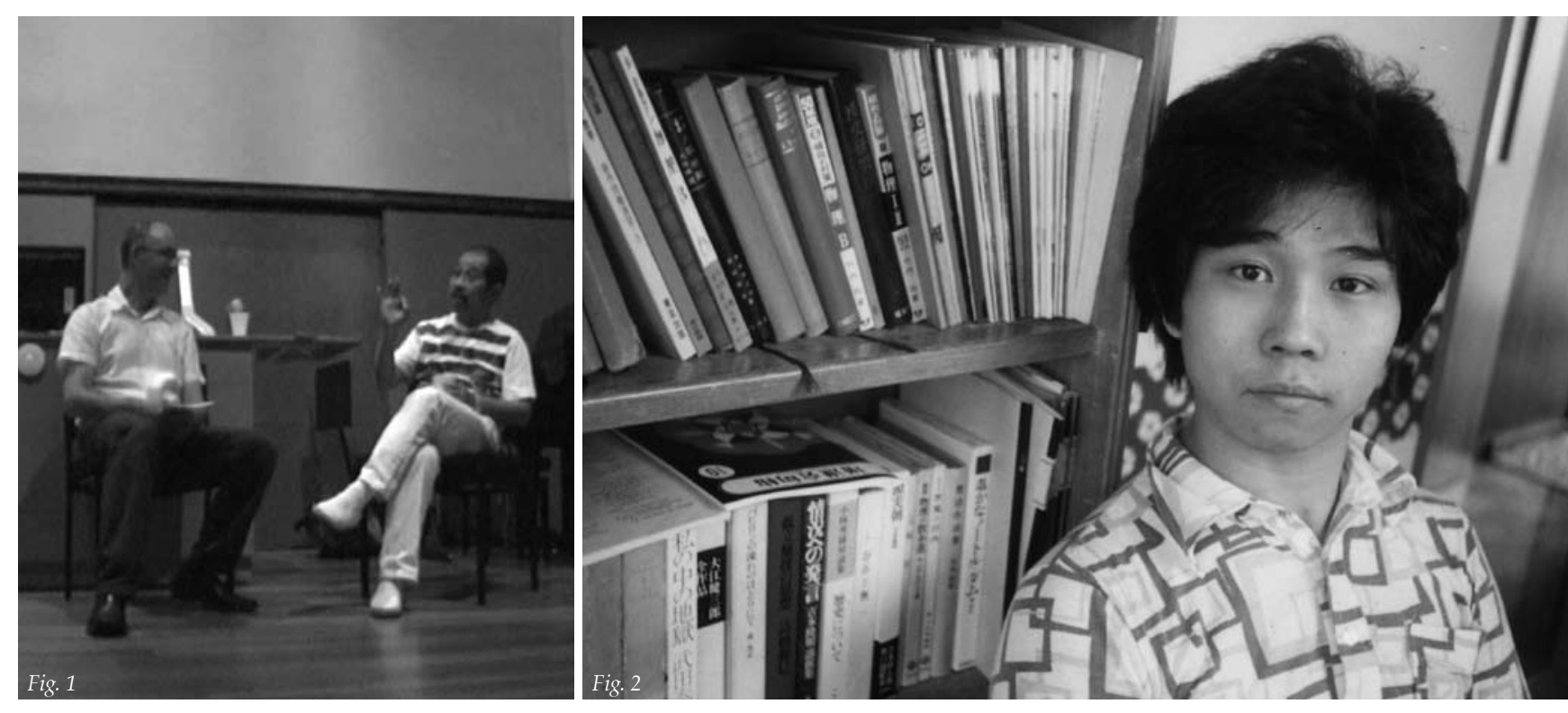

Fig 1: Andrew Barrie and Jun Aoki in conversation in The University of
Auckland's Design Theatre. From video
by Josh Stetwart.

Fig 2: : Jun Aoki during his university
years. Photograph courtesy of Jun Aoki.

tremely well. However, my test for mathematics went very, very badly - I scored zero [laughs]. The test takes about 90 minutes, but I couldn't understand the questions. So, I forgot about being a writer and decided to become an architect. After graduating from high school I decided to re-sit the entrance exam, and studied very very hard for a year - we call it ronin [master-less warriors]. I spent studied very, I was at high school I was in a band, and had no time to study.

\section{What kind of band?}

Rock. I'm now 51, but when I was at high school Led Zeppelin was the most famous and interesting band in the world, so I played guitar like Jimmy Page. I even had the hair [laughs]. Anyway, when I decided to apply for university I sold all my instruments and stopped playing. After I passed the entrance test, bought a piano.

Do you still play?

No. It's too difficult to learn the piano...

\section{Tell us about your time at university.}

In Japan, Tokyo University is special because the undergraduate course is four years long. The first two years aren't specialized architectural training - it's exactly the same course for all the engineering disciplines.

This is the general course within the School of Engineering.

Yes. You then have to decide what specialization to do, and have just two furthe years of study. When I began the architecture program, I was very shocked by the kadai [studio project]. This involved some virtual project, for which the students had to prepare a proposal to meet the requirements. It was the first time I felt really enthusiastic about something. I didn't want to sleep or to eat, because I was having so much fun [laughs]. It was very, very interesting. I didn't want to go to university for structural courses or mechanical courses - just design. I knew very few of the professors - I never met them because I didn't go into the

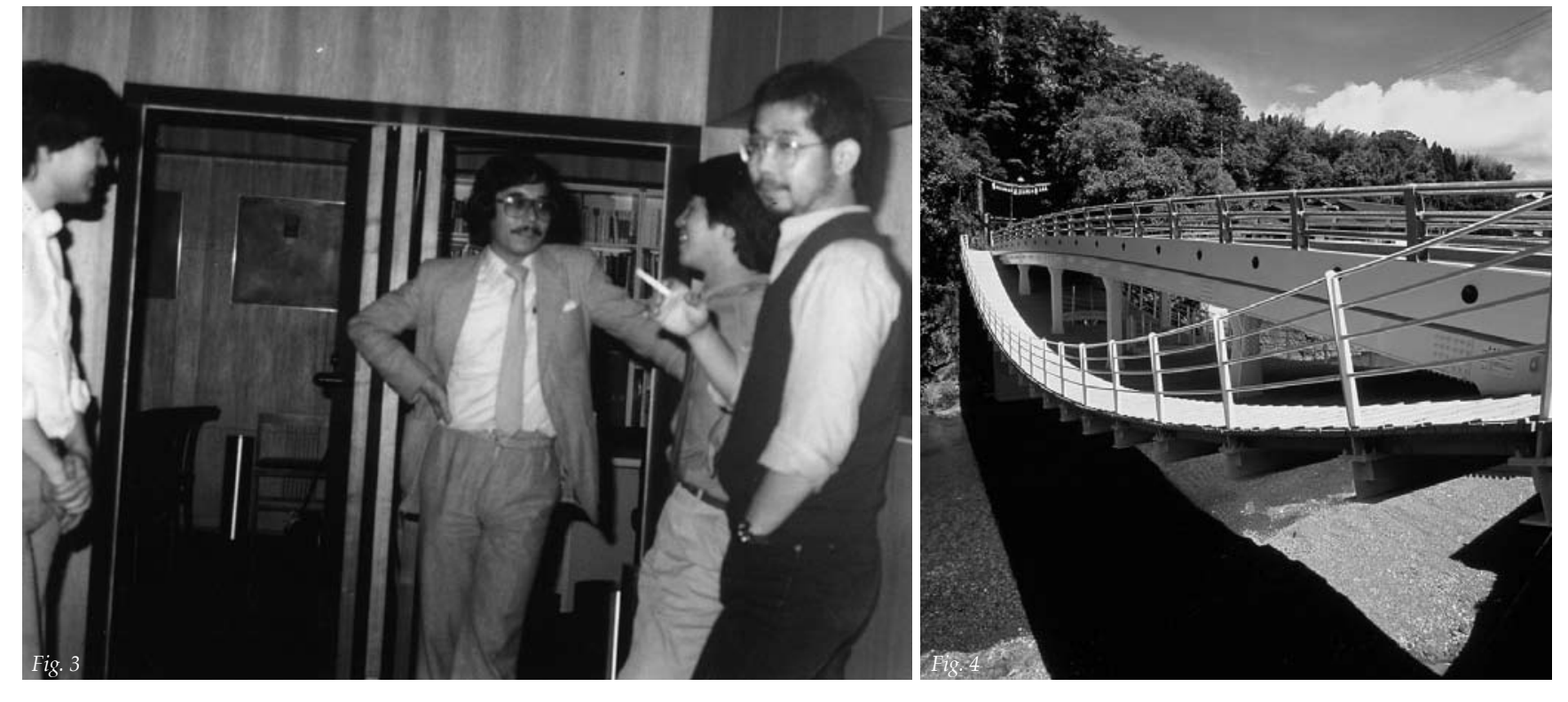

university. I just made drawings and models, and one day a week I'd go to the university to show my ideas. That was my university experience.

Who were the professors of architecture at Tokyo University at that time?

When I began the architecture course, Yoshinobu Ashihara was a professor-he's a kind of father of Japanese modernism. Then Fumihiko Maki came to the university, so we learned from Maki-san and Ashihara-san. We also we had gues professors like Arata Isozaki, Kazuo Shinohara and other architects. Tokyo is a huge city, and 80 percent of Japan's architects live there, with only 20 percent living in Osaka - like Ando-san - or other areas. I think Tokyo is a very special city - at Tokyo University, lots of architects were invited to teach the students.

\section{When those outside architects came into the School, how did they teach?}

It was very, very interesting, as it was a kind of presentation of the architects themselves. I remember Shinohara-san's class - his kadai proposed that if you believe originality grows from the process of copying, what kind of architecture can you make? So, everybody had to make a copy, but in a very original way. It was very, very interesting - it wasn't so much teaching as a presentation of Shinohara-san's own philosophy about architecture.

\section{How did you come to work for Isozaki-san?}

I graduated the undergraduate program and entered the Masters course. After two years of Masters study, I entered the doctoral course. I wanted to be an architect but I had no work - nobody asked me to design anything. So, little by little, I concluded that I had to go to a real studio to learn to be an architect. So, I asked my university professor to find out the possibility of my entering Arata Isozaki's office. I met Isozaki-san, and he told me his office was then fully staffed, but he said, "If you want to wait to enter, that's OK, but I can't say whether or not you'll I went to his office.
Fig 3: Jun Aokiat Isozaki's atelier.
Photograph courtecy of Iun Aoki. Fig 4: Jun Aoki, Mamihara Bridge, Photograph courtesy of The Iapan Foundation. 
I should clarify for the Kiwis that 'entering' this kind of office in Japan is not a clear cut process. It's usually provisional, and not everyone makes the grade. But you obviously did...

I worked at Isozaki-san's office for about seven years, including several very interesting projects such as the Tokyo City Hall Competition. However, I wash

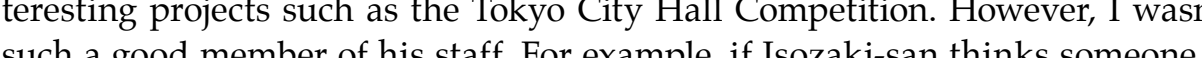
such a good the best member or his staff, then they ll work on international competitions there are lots of competitions - but Isozaki-san asked me to design very small projects - very, very small [laughs], like private houses, the renovation of his own house, and the renovation of the office. But, it was very good for me because I learned from the contractors how architecture is built. Otherwise, a lot of the work in Isozaki-san's office is very, very big, so the staff don't know about the architectural details but just work on the planning and think about landscape or urbanism. But I started from the details - it was a great chance to learn about architecture.

\section{How did you establish your own office?}

After seven years working in Isozaki's office, I became independent. However I had no idea of what kind of things I could do, but I was keen to do anything interesting. So, my first project was a study of office space - not design, but thinking about future working styles, and so on. My second job was thinking about virtual architecture. I worked for three years or so, and eventually I got my first project in Japan. It was Mamihara Bridge - a small bridge that wa Kumamoto Artpolis project.

As you were establishing yourself, did you feel you were moving with or against the general current of contemporary architecture?

I didn't care about my position. When I started my own work, rather than becoming a famous architect, I just wanted to make something interesting. So, I don t read architectural magazines at all. Of course, publishers send us copies of their magazines, but it takes me only about one minute to get through each magazine,

and so I don't know much about architectural trends or architecture in general.

\section{What was your relationship with other architects in your generation?}

I think you all know about Tadao Ando and Toyo Ito. Ando-san and Ito-san are from the same generation. They're the same age $-\mathrm{I}$ think they are now about 67 years old. Sejima-san and I are the same age - we have almost the same birthday. My birthday is October $22^{\text {nd }} 1956$.

\section{These students will all send you a birthday card...}

Sejima-san's birthday is October $29^{\text {th }}$. When we were university students we'd celebrate our birthdays at the same party [laughs]. Anyway, there is a very large and important gap between Ito and Ando's generation and our generation. After the Second World War, Japan's cities had all been reduced to ashes by the bombing. Every architect needed to build new buildings and new cities from this tabula rasa. But by the 1980s or 90s Japan's modernization was complete, so when our generation started working almost every piece of land in Japan was built up. So we didn't want to make new designs, but to renovate something or to muit up. So we did't wanto wake make something from our own private inger but to ren and Ito-san feel sone kind of responsibility towards Japan as a nation, but honestly speaking I don't feel much of this kind of responsibility.

\section{What contact do you have with the other architects of your generation?}

Well, my generation is Kazuyo Sejima, Kengo Kuma, Shigeru Ban, and a few others. We can really only meet outside Japan - in foreign cities like Zurich - at was in New York, and before that we contact in Japan.

You talked a little bit about magazines. Because we in New Zealand are so far from the rest of the world, we're very dependent on magazines to find out what's going on. But you suggested that maybe it's not so useful to look at magazines.

Of course, when you're a student it can help you. However, when you graduate from school, you have to have some originality - you have to find out what you want. So the information in magazines isn't so important. Well... this is definitely the case in Tokyo. If we compare Tokyo as a city with Osaka, everyone in Osaka is very attentive to information from all around the world - I'm often shocked by their knowledge of architecture. Of course, the important thing isn't to know the new architectural trends but the most interesting things in the world. If these things aren't architecture, that's OK - art is OK, I think, or something about chemistry or physics or biology - anything. Anything that you're very, very interested in is OK - these things become the seeds of your inspiration.

\section{Do you have any advice for students who are just beginning to start their archi-} tectural studies?

Well... for me, the most interesting and most important training in architecture is a kind of testing. You need lots of discussion or comments on your projects, not only in terms of architecture but from other faculties or other people. If you receive lots of comments on your projects, you can analyze your situation and your natural tendencies in architecture. From this you can clarify the image of your own architecture - creating your own image is the most important thing.

\section{What's your definition of a good architect?}

A good architect has to provide some new translation of space or of material. Everybody has a common understanding of space or materials or ... everything really, and the role of a good architect is to change these preconceptions.

\section{When you are looking for young graduates to join your staff, what kind of person} do you look for?

My studio has from twelve to fifteen staff members, all very young. Each person can stay in the office for just four years, which makes it like a kind of university. So, it's a very, very young firm. About 100 people send us resumes or portfolio each year, and I meet several of those applicants to decide if they can enter the studio. The criteria aren't secret - it's very much the usual stuff. For me, I like students who will make almost the same things in the studio as they did when they were a student. Looking at the portfolios, sometimes not-so-smart guys use the same idea for every project. They have one idea, for example, in a house project, but for their museum they use the same idea, and their commercial market, the same idea, and so on. These students have only one idea, but it's very strong. I like them very $\mathrm{m}$ their minds and find a trendier architecture, but there's some reason why they can't move on, so I'm very curious about them. This is my only criteria. 